\title{
FILTER AIR BERSIH MENGGUNAKAN KERAMIK BERPORI STUDI KASUS DI KABUPATEN DEMAK
}

\author{
Muhammad Amirur Rokhim*, Sri Mulyo Bondan Respati, Muhammad Dzulfikar \\ Jurusan Teknik Mesin, Fakultas Teknik, Universitas Wahid Hasyim Semarang \\ Jln. Menoreh tengah X/22, Sampangan, Semarang, Indonesia \\ *Email: Amirradyansah@gmail.com
}

\begin{abstract}
Abstrak
Penggunaan membran dari keramik akhir-akhir ini di Indonesia mulai meningkat karena membran keramik mempunyai kandungan kimia yang bagus, tahan terhadap panas dan kekuatan yang setabil. penggunaan membran keramik ini semakin meningkat dengan pengaplikasian sebagai filter atau penyaring. Tetapi proses pembuatan dan bahan yang digunakan cukup mahal, maka dari itu penelitian dengan metode mencampurkan bahan lain seperti karbon aktif ini dilakukan, arang tempurung kelapa dan arang sekam padi yang banyak dijumpai mempunyai kemampuan daya serap tinggi (absorpsi) yang baik. Penelitian ini menghadirkan campuran bahan zeolit alam dengan penambahan karbon aktif sebagai bahan campuranya dengan suhu pembakaran $900^{\circ} \mathrm{C}$. keramik berpori dibentuk berupa silinder diteliti. Menggunakan Pengukuran densitas dan porositas atau disebut metode arschimides. uji kecepatan alir air dan pengujian nilai TDS (Total Dissolved Solid). Hasil pengujian kandungan Air sebelum disaring dan setelah disaring ICP (inductively coupled plasma) keramik berpori mampu menurunkan nilai-nilai unsur yang terkandung didalam air. hal ini tidak luput dari penggunaan campuran karbon aktif yang terbukti mampu menurunkan kandungan unsur didalam air. serta mampu menurunkan nilai TDS air. laju aliran air juga meningkat sehubungan dengan bertambahnya jumlah campuran karbon aktif yang dilakukan. Dikarenakan semakin banyak pori-pori atau rongga didalam material keramik yang disebabkan oleh terbakarnya karbon aktif disaat proses sintering.
\end{abstract}

Kata kunci: arang sekam padi, arang tempurung kelapa, sifat fisik, zeolit.

\section{PENDAHULUAN}

Zeolit merupakan batuan alam yang mengandung mineral Kristal alumina silica dan banyak dijumpai dicelah-celah batuan basa. Zeolit memiliki struktur berongga dan mampu menyerap molekul-molekul yang melewatinya (Kurniasari dkk., 2011) unsur yang terkandung didalam zeolit diantaranya. Alumunium oksida $\left(\mathrm{Al}_{2} \mathrm{O}_{3}\right)$, Asam silikat $\left(\mathrm{SIO}_{2}\right)$, Kalium oksida $\left(\mathrm{K}_{2} \mathrm{O}\right)$. dan lain-lain. Zeolit adalah mineral Kristal alumina silica berpori terhidra yang sering digunakan sebagai media penyaring air. karena struktur zeolit yang berongga dan sifat zeolit yang mampu menyerap molekul-molekul yang berukuran sesuai dengan rongganya atau bahkan ukuran yang lebih kecil. Sifat inilah yang menjadikan zeolit banyak digukanan dalam industri kecil maupun besar sebagai media penyaringan limbah.

Air merupakan unsur yang sangat penting bagi kehidupan manusia, keadaan lingkungan yang kurang baik biasanya berpengaruh dengan kualitas dan kondisi air yang terkandung di dalam tanah begitupun sebaliknya, Nilai TDS (Total Disolved Solids ) dijadikan sebagai acuan untuk nilai standar Air yang ingin dikomsumsi oleh masyarkat.

Keramik berpori biasa digunakan sebagai media penyaring air, dikarenakan didalam keramik berpori ini terdapat rongga-rongga kecil yang mampu mengikat molekul-molekul yang seukuran denganya, selain itu alasan keramik berpori dipilih karena sifat dari keramik yang mampu bertahan dalam perubahan suhu tinggi dan tahan terhadap kontaminasi dengan bahan lain (Sandra dkk., 2014).

Tempurung kelapa adalah bagian dari buah kelapa yang menyelimuti daging kelapa bersifat keras dan berserabut. Tempurung kelapa biasanya hanya menjadi limbah dan dijadikan sebuah arang, arang tempurung adalah hasil dari pembakaran yang tidak sempurna. Setelah diteliti Arang tempurung kelapa ternyata memiliki sifat 
karbon atau media penyerap alami yang baik dibandingkan dengan jenis arang lainya.

Arang sekam padi atau sekam padi bakar adalah hasil dari proses pembakaran tidak sempurna, sekam sendiri adalah kulit dari biji padi yang telah dikupas biasanya menjadi limbah yang kurang diperhatikan di mata masyarakat, arang sekam memiliki kandungan karbon tinggi selain mudah dijumpai, arang sekam padi memiliki sifat penyaring alami (absorben) yang baik, hal ini yang menyebabkan arang sekam padi banyak digunakan sebagaai media tanam dan arang akif untuk menjernihkan air.

Dalam penelitian kali ini akan dirancang suatu keramik berpori dengan menggunakan bahan zeolit alam, dengan campuran bahan lain yaitu arang sekam padi dan arang tempurung kelapa yang kemudian akan melewati proses pembubukan, pencampuran yang berfariasi, pengepresan dengan tekanan tertentu. dan tahap akhir disinterring dengan suhu sintering tertentu.

Penelitian ini mertujuan untuk mengetahui pengaruh dari pencampuran bahan lain yaitu karbon aktif terhadap sifat fisik keramik berpori, laju aliran air, nilai TDS (Total Disolve Solid), dan mengetahui seberapa besar nilai unsur pada air sebelum dan sesudah air disaring menggunakan saringan keramik berpori berbasis zeolit alam arang sekam padi dan arang tempurung kelapa. dengan Menggunakan alat ICP( inductively coupled plasma).

\section{METODE PENELITIAN}

Sampel dibuat dengan menggunakan bahan zeolit yang dicapmpur dengan arang. Hasil pembakaran tempurung kelapa dan sekam padi yang berupa arang dicampur dengan zeolit. Proses berikutnya adalah dilakukan perlakuan sintering. Setekah spesimen dibuat dilanjutkan dengan proses pengujian. Uji XRF ( $X$-Ray Fluorescence) dan uji karakteristik untuk analisis pengaruh kandungan campuran dari karbon aktif tersebut, kemudian dilakukan pengujian susut, densitas, porositas dan uji laju air. Pengujian densitas ada 2 yaitu bulk densitas dan Archimedes densitas.(Pratama \& Prakoso, 2015).
Pengujian kejernihan air menggunakan TDS untuk mengetahui jumlah padatan yang terkandung di dalam air (Berger, 2010).

kandungan unsur-unsur dalam air diukur menggunakan ICP (Razi 2012).

Susut volume $=\frac{V_{o}-V_{t}}{V_{o}} \times 100 \%$.

Susut massa $=\frac{m_{o}-m_{t}}{m_{o}} \times 100 \%$

Bulk densitas $=\frac{m_{t}}{V_{t}}$.

Archimedes densitas $=\frac{m_{t}}{m_{t}-m_{a}} \times \rho_{\text {air }} . .(4)$

Porositas $=1-\frac{V_{s}}{V_{t}} \times 100 \%$

Volume spesimen $\mathrm{V}_{\mathrm{S}}=\frac{m_{t}-m_{a}}{\rho_{\text {air }}}$.

dimana:

$\mathrm{V}_{\mathrm{o}}=$ Volum sampel awal $\left(\mathrm{cm}^{3}\right)$

$\mathrm{V}_{\mathrm{t}}=$ Volum sampel akhir $\left(\mathrm{cm}^{3}\right)$.

$\mathrm{m}_{0}=$ Massa sampel sebelum dipanaskan (gram)

$\mathrm{m}_{\mathrm{t}}=$ Massa sampel sesudah dipanaskan (gram).

$\mathrm{m}_{\mathrm{a}}=$ Massa sampel di dalam air (gram).

$\mathrm{V}_{\mathrm{s}}=$ Volume spesimen sesudah sampel dipanaskan $\left(\mathrm{cm}^{3}\right)$

$\mathrm{m}_{\mathrm{t} \text { porositas }}=$ Massa sampel diudara $(\mathrm{gram})$

$\rho=$ Air sebelum disaringPengujian ICP

\section{HASIL DAN PEMBAHASAN}

Dalam penelitian pembuatan membran keramik berpori berbasis zeolit alam, arang sekam padi dan arang tempurung kelapa. Penelitian ini menggunakan 5 variasi pencampuran bahan dan 3 sampel. Berikut hasil karakterisasi pengujian susut pemanasan, densitas, porositas, kekerasan, laju aliran air dan nilai TDS. Pengujian susut pemanasan ada 2 yaitu susut volume dan susut massa, berikut data dalam Gambar 1.susut pemanasan.

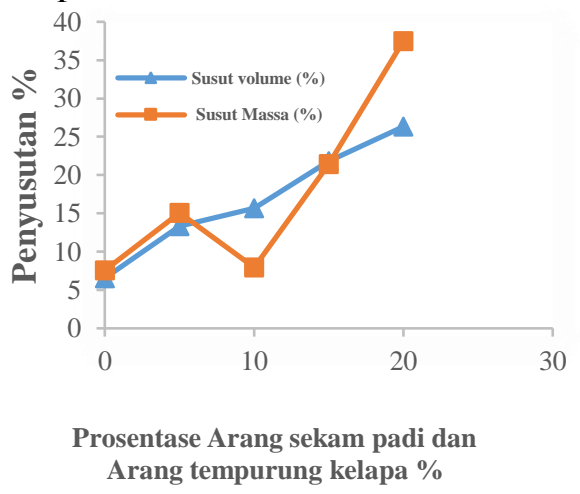

Gambar 1. Susut pemanasan 
Dari hasil melihat grafik dapat diketahui hasil susut volume dan susut massa berbanding lurus semakin banyak campuran arang semakin besar penyusutan terhadap volume dan massa pada material keramik tersebut, ini dikarenakan arang yang terdapat di dalam material terbakar saat proses sintering sehingga menimbulkan rongga atau pori-pori dalam material keramik tersebut. hal ini mengakibatkan berat pada material kermik mengalami penyusutan, susut pemanasan menyebabkan hilang nya air yang dikandung bahan keramik antar butiran zeolite, arang sekam padi dan arang tempurung kelapa yang saling mengikat. Berikut data pada Gambar 2. Densitas.

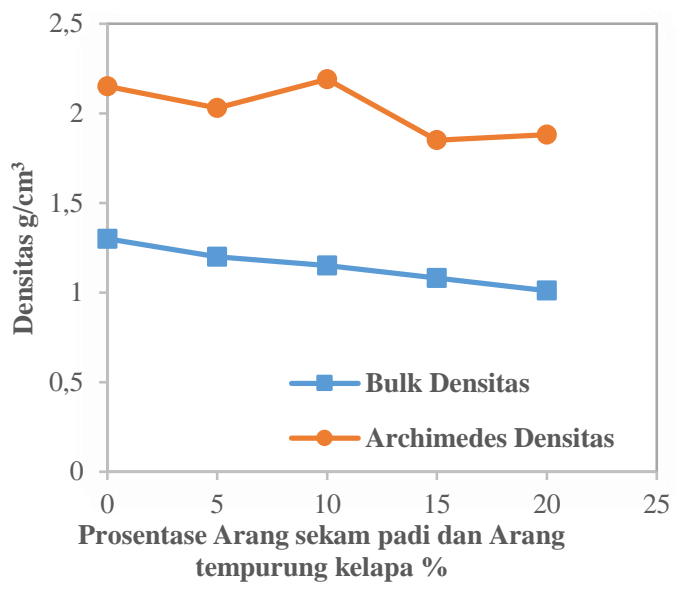

\section{Gambar 2. Densitas}

Melihat hasil dari data dan gambar 2 semakin sedikit campuran arang semakin tinggi nilai kerapatannya. Sedangkan pada archimides densitas terkecil dengan perbandingan zeolite dan arang $0 \%$. Terbesar terjadi pada perbandingan zeolite dan arang 20\%. Sehingga semakin banyak campuran arang maka nilai archimides densitas semakin tinggi dan nilai kerapatannya semakin kecil. Karena nilai densitas berpengaruh terhadap porositas dari suatu material keramik. Semakin banyak prosentase arang maka semakin kecil nilai kerapatan dari material keramik tersebut. Hasil perhitungan archimides densitas pada penelitian ini nilai terbesar berada dicampuran zeolite dan arang 90\%;10\% yang seharusnya nilai terbesar berada di campuran zeolit dan arang 80\%;20\%. Ada kemungkinan terjadinya kegagalan dikarenakan ketika proses pengadukan hasilnya kurang merata dan waktu proses penekanan kurang lama. Menyebabkan butiran zeolit dan arang kurang mengikat. Ketika sesudah disentering kerapatan yang terjadi nilainya berkurang dari hasil campuran yang seharusnya. Hasil pengujian porositas dapat dilihat pada Gambar 3. Porositas

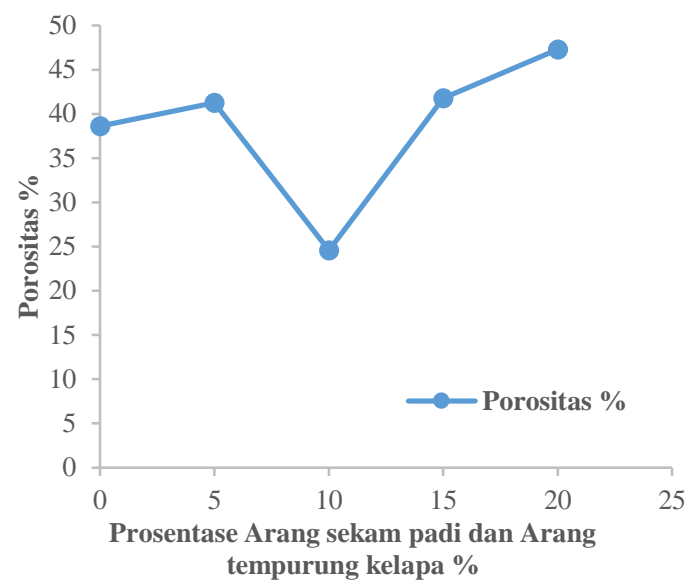

Gambar 3. Porositas

Gambar 3 menunjukan tingkat porositas dimana prosentase campuran antara zeolit dan arang sangat berpengaruh terhadap hasil porositas. Sehingga hasil ini dapat diketahui bahwa semakin banyak arang sekam padi dan arang tempurung kelapa yang terkandung pada material keramik maka nilai porositasnya material tersebut akan semakin tinggi. dikarenakan material tersebut mengandung banyak rongga. Secara fisik penggunaan campuran arang juga akan berpengaruh terhadap berat maupun volume keramik tersebut.

Pada Gambar.3 porositas menunjukan penurunan nilai grafik pada campuran zeolite arang sekam padi dan arang tempurung kelapa 90\%;10\% hal ini kemungkinan terjadinya kegagalan dikarenakan ketika proses pengadukan hasilnya kurang merata dan waktu proses penekanan kurang lama. Menyebabkan butiran zeolit, arang sekam padi dan arang tempurung kelapa kurang mengikat. Ketika sesudah disentering kerapatan yang terjadi nilainya berkurang dari hasil campuran 
yang seharusnya. Hal ini dapat dilihat secara fisual ketika pengujian porositas material keramik dimasukan ke dalam air. keramik mengalami kropos dan ketika diangakat dari dalam air bentuk keramik tidak lagi sempurna. Hasil pengujian laju aliran air dapat dilihat pada Gambar 4 Laju aliran Air

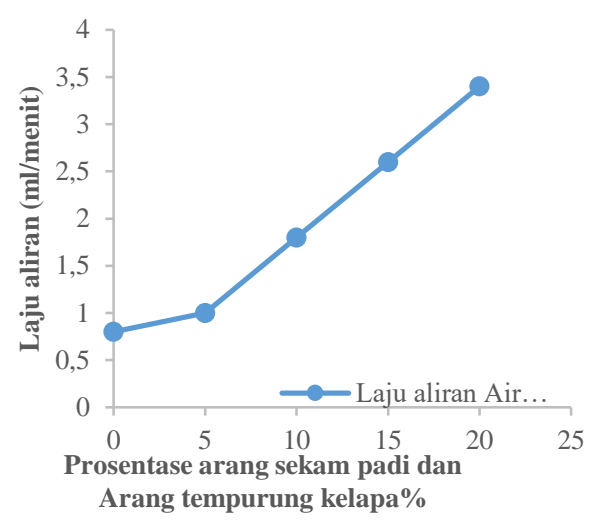

\section{Gambar 4. Laju aliran air}

Melihat hasil dari data dan grafik menunjukan grafik pengujian laju aliran air, dimana semakin banyak campuran arang. Maka semakin cepat pula laju aliran air ketika proses penyaringan. Hal ini disebabkan oleh adanya rongga yang terdapat didalam keramik hal ini terjadi ketika proses terbakarnya arang saat proses sintering. pengikatan antara zeolit dan arang menciptakan rongga-rongga didalam material keramik. Uji TDS air (Total dissolve solid). Hasil pengujian TDS (Total dissolve solid) dapat dilihat pada Gambar 5. UJi TDS air

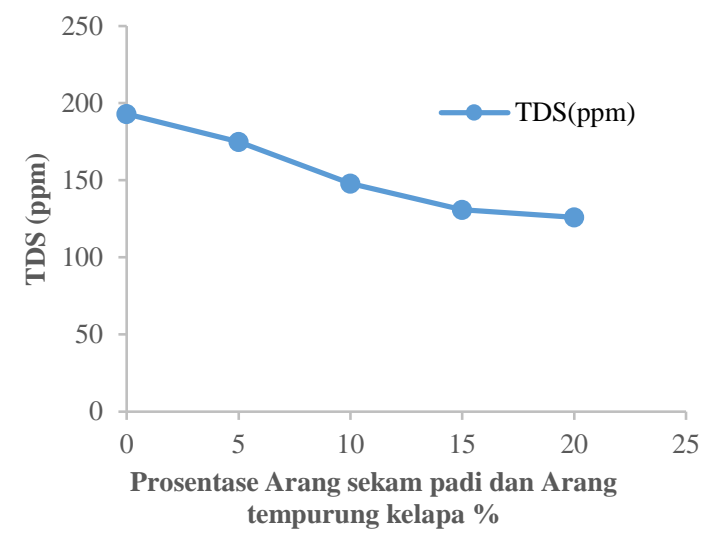

Gambar 5. UJi TDS air
Dari hasil melihat data dan grafik menunjukan hasil pengujian TDSair mengalami penurunan. Nilai ppm yang dipengaruhi oleh penambahan arang yang berbeda-beda. Hasil tersebut dapat diketahui bahwa semakin banyak penambahan arang pada keramik berbasis zeolit alam, maka semakin kecil nilai ppm nya dan hasil penyarigan air yang dihasilkan akan semakim baik kaeran nilai ppm air dapat diketahui dari tinggi rendah nya nilai ppm yang semakin kecil. Hal ini disebabkan karena arang sebagai karbon aktif yang sangat baik dan sebagai absorben atau penyerap zat-zat yang melewati arang tersebut. tetapi hasil penyaringan ini menunjukan nilai ppm air sanitasi tidak air murni ataupun air layak minum.

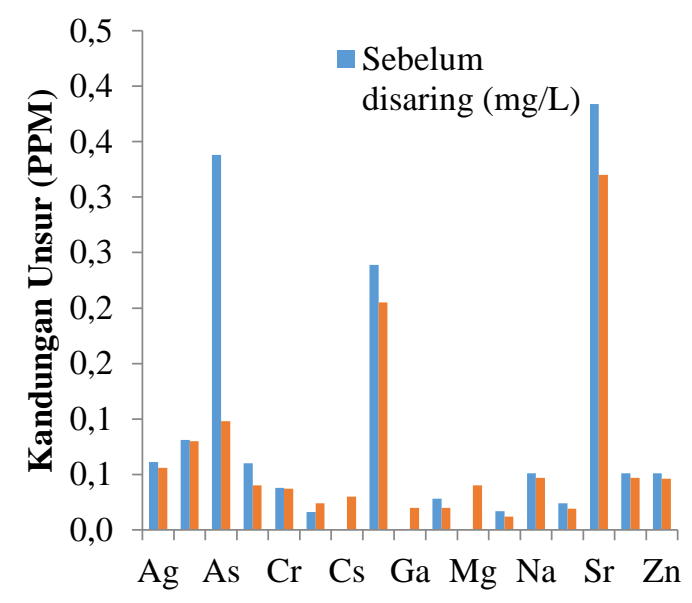

\section{Gambar 6. Uji ICP}

Dari hasil uji ICP. Keramik berpori berbasik zeolit alam dan arang terbukti mampu menurunkan kandungan nilai unsur dalam air. Adapun unsur-unsur yang sebelum air disaring nilai nya 0 , dan setelah disaring nilainya menjadi naik seperti $\mathrm{Cs}$, $\mathrm{Ga}, \mathrm{Mg}$. setelah melihat hasil uji komposisi bahan. XRF (Xray Fluorensence) dari zeolit, arang sekam padi dan arang tempurung kelapa tiga unsur tersebut tidak terkandung didalam salah satu bahan antara zeolit, arang sekam padi maupun arang tempurung kelapa, hal ini dapat disimpulkan bahwa adanya kemungkinan terjadinya eror pada alat uji kandungan air atau ICP (Inductively Coupled Plasma). 


\section{PENUTUP}

\section{Kesimpulan}

Berdasarkan dari hasil penelitian yang dilakukan, maka dapat disimpulkan bahwa. Pada pengujian susut pemanasan di lakukan dengan dua pengujian yaitu susut volume dan susut massa. hasil dari pengukuran susut volume pada perbandingan zeolite, arang sekam dan arang tempurung kelapa $0 \%, 5 \%$, $10 \%, 15 \%$ dan $20 \%$ adalah 6,$56 ; 13,36$; 15,$65 ; 21,80$ dan 26,32 sedangkan pada susut massa adalah 7,$57 ; 15,10 ; 7,97 ; 21,45$ dan 37,5 .

Hasil pengujian nilai porositas tertinggi terjadi pada campuran zeolite, arang sekam padi dan arang tempurung kelapa $20 \%$ adalah $47,28 \%$ sedangkan nilai porositas terkecil terjadi pada campuran zeolite, arang sekam padi dan arang tempurung kelapa $10 \%$ adalah $24,57 \%$. Dari hasil analisa diketahui bahwa semakin tinggi nilai porositas yang dihasilkan maka semakin rendah nilai densitasnya. Semakin banyak penambahan arang sekam padi dan arang tempurung kelapa maka semakin tinggi laju aliran air yang didapatkan. Pada pengujian TDS diketahui bahwa semakin banyak campuran arang sekam padi dan arang tempurung kelapa maka semakin tinggi nilai kemurnian air dan menghilangkan kandungan logam didalam air. Kandungan karbon aktif, mampu menurunkan nilai-nilai unsur yang terkandung didalam air.

\section{DAFTAR PUSTAKA}

Berger, M. B. (2010). The importance and testing density/porosity/permeability/pore size for refractories. The Southern African Institute of Mining and Metallurgy http://www.saimm.co.za/Conferences /Refractories2010/101-

116_Berger.pdf

Kurniasari, L., Djaeni, M., \& Purbasari, A. (2011). Aktivasi zeolit alam sebagai adsorben pada alat pengering bersuhu rendah. In Reaktor. ejournal.undip.ac.id.

https://ejournal.undip.ac.id/index.php/ reaktor/article/view/3180

Pratama, M. A., \& Prakoso, G. Y. (2015). X-
Ray Fluoresence (Nomor 1206238936).

https://adoc.pub/universitasindonesia-x-ray-fluoresence-tulisanilmiah-muham.html

Sandra, K. O., Budi, A. S., \& Susilo, A. (2014). Pengaruh Suhu Sintering Terhadap Densitas dan Porositas pada Membran Keramik Berpori Berbasis Zeolit, Tanah Lempung, Arang Batok Kelapa, dan .... Jurnal Fisika, Fakultas Matematika dan Ilmu .... 